Originally published as:

Aurass, P., Prager, R. and Flieger, A. (2011), EHEC/EAEC O104:H4 strain linked with the 2011 German outbreak of haemolytic uremic syndrome enters into the viable but non-culturable state in response to various stresses and resuscitates upon stress relief. Environmental Microbiology. doi: 10.1111/j.1462-2920.2011.02604.x

DOI: $10.1111 / \mathrm{j} .1462-2920.2011 .02604 . \mathrm{x}$

This is an author manuscript.

The definitive version is available at:

http://onlinelibrary.wiley.com/doi/10.1111/j.1462-2920.2011.02604.x/abstract 


\title{
EHEC/EAEC O104:H4 strain linked with the 2011 German outbreak of haemolytic uremic syndrome enters into the viable but non-culturable state in response to various stresses and resuscitates upon stress relief
}

\author{
Philipp Aurass, ${ }^{1}$ Rita Prager $^{1,2}$ and Antje Flieger ${ }^{1,2}$ * \\ ${ }^{1}$ Division of Bacterial Infections (FG11), and \\ 2 National Reference Centre for Salmonella and other Enteric Bacterial Pathogens, Robert Koch- \\ Institut, Burgstr. 37, D-38855 Wernigerode, Germany.
}

\begin{abstract}
Various non-spore forming bacteria, including Escherichia coli, enter a dormant-like state, the viable but non-culturable (VBNC) state, characterized by the presence of viable cells but the inability to grow on routine laboratory media. Upon resuscitation, these VBNC cells recover both culturability and pathogenicity. In 2011, a large outbreak involving more than 3000 cases of bloody diarrhoea and haemolytic uremic syndrome was caused by an E. coli O104:H4 strain

expressing genes characteristic of both enterohaemorrhagic (EHEC) and enteroaggregative E. coli $(E A E C)$. The ability of the outbreak strain to enter the VBNC state may have complicated its detection in the suspected sources. In this paper, we investigated the ability of the outbreak strain to enter and subsequently recover from the VBNC state.We found that in a nutrient-poor micro-environment, various stresses such as toxic concentrations of copper ions or certain types of tap water are able to render the bacteria unculturable within a few days. Without copper ion stress, the majority of cells remained culturable for at least 40 days. Incubation with the stressors at $23^{\circ} \mathrm{C}$ compared with $4^{\circ} \mathrm{C}$ hastened this observed loss of culturability. The integrity of a considerable fraction of copper ion- and tap water 1-stressed bacteria was demonstrated by live/dead staining and microscopy. Relieving stress by copper-ion chelation facilitated resuscitation of these bacteria while preserving their fitness, major virulence gene markers (stx2, aggR, aggA genes) and specific phenotypes (ESBL resistance, autoaggregation typical for EAEC strains).
\end{abstract}

\section{Introduction}

In 2011 an enterohaemorrhagic (EHEC)/enteroaggregative Escherichia coli (EAEC) hybrid strain of serotype 0104:H4 expressing genes for Shigatoxin 2a (stx2a), AAF/l fimbriae (plasmid-coded) and extended spectrum $\beta$-lactamase resistance (ESBL) (plasmidcoded) caused a large outbreak of haemolytic uremic syndrome (HUS) and bloody diarrhoea in northwestern Germany (Askar et al., 2011; Bielaszewska et al., 2011; Brzuszkiewicz et al., 2011; Cui et al., 2011; Frank et al., 2011; Mellmann et al., 2011; Scheutz et al., 2011). From early May through July 26th 2011, 3052 cases of EHEC diarrhoea and 733 cases of HUS, which resulted in the deaths of a total of 45 people, were reported to the German public health authorities (RKI, 2011a).

Whereas E. coli $\mathrm{O} 157: \mathrm{H} 7$ or $\mathrm{O} 157: \mathrm{H}-(\mathrm{NM})$ are the primary EHEC serotypes associated with development of HUS and bloody diarrhoea, EAEC are strongly linked to diarrheal illness in Africa, Latin America, Asia, but also in Europe and North America (Adachi et al., 2001; Karch and Bielaszewska, 2001; Kaper et al., 2004; Harrington et al., 2005; Tarr et al., 2005; Huang et al., 2006; Pennington, 2011). Until the year 2011 only a few EHEC/EAEC 0104:H4 strains have been isolated from patients (Scheutz et al., 2011). One of these is the EHEC/EAEC strain HUSEC041 isolated from a HUS patient in 2001, which is genetically related to the recent outbreak strain with some important differences, such as its encoding of AAF/III instead of AAF/I fimbriae and its lack of ESBL resistance (Mellmann et al., 2008; 2011). 
Several lines of evidence point to fenugreek sprouts and seeds as culprit sources of contamination (BfR+BVL+RKI, 2011; Gault et al., 2011; RKI, 2011b). However, the outbreak strain was detected in suspect food only in a small minority of cases, for example in an already opened package of sprouts from a household with disease (BfR, 2011). With respect to the fenugreek seeds from suspect origins, neither detection nor isolation of the E. coli O104:H4 outbreak strain has been possible thus far. The failure to isolate the EHEC/EAEC outbreak strain may have several reasons. For example, the bacteria may exist in the environment in a dormant state, such as the viable but non-culturable (VBNC) state, and detection by culture-based approaches may be possible only under certain conditions.

Many different bacterial species, including $E$. coli, are known to enter the VBNC state when under stressful environmental conditions, such as lack of nutrients, unfavourable temperatures or, the presence of toxic metal ions (Kell et al., 1998; Barer and Harwood, 1999; Oliver, 2005; 2010). Although alive and metabolically active at a low level, bacteria in the VBNC state do not grow on bacteriological media in which they would normally grow under a culturable state (Rahman et al., 1994). VBNC cells may regain culturability when resuscitated, which in some cases is driven by stress relief (Xu et al., 1982; Wingender and Flemming, 2011). VBNC cell formation has been shown for nonpathogenic E. coli but also for EHEC 0157:H7 (Xu et al., 1982; McKay, 1992; Mizunoe et al., 1999; Grey and Steck, 2001; Yaron and Matthews, 2002; Pinto et al., 2011). Numerous VBNC-inducing factors have been reported; with respect to $E$. coli, these include nutrient starvation (Smith et al., 1994; Pinto et al., 2011), and high copper-ion concentrations (Grey and Steck, 2001). Once VBNC state cells are established, they may persist for long periods of time. Survival of E. coli O157:H7 for several months in water or soil environments, even in conditions of dryness that were initially thought to be critical, has been observed (Wang and Doyle, 1998; Bolton et al., 1999; Jiang et al., 2002).

Although the pathogenicity of VBNC cells per se is controversial, there is irrefutable evidence that recovered cells regain virulence, for example by animal passage, and may cause disease (Colwell et al., 1985; Rollins and Colwell, 1986; Stern et al., 1994; Oliver and Bockian, 1995). Nevertheless, even continuous Shiga-like toxin production or stx1 gene expression has been shown for VBNC state EHEC O157:H7 (Yaron and Matthews, 2002; Liu et al., 2010). Recovery of virulence after resuscitation was demonstrated in a range of microorganisms, such as Vibrio cholerae, Campylobacter jejuni (Jones et al., 1991; Saha et al., 1991), Legionella pneumophila (Hussong et al., 1987; Steinert et al., 1997) and Shigella dysenteriae (Rahman et al., 1994; 1996; Colwell et al., 1996). The VBNC phenomenon may therefore represent a health and surveillance problem due to the almost universally used culturebased pathogen detection methods.

Because the German E. coli 0104:H4 outbreak strain represents a novel hybrid bacterium composed of genes characteristic of EHEC and EAEC (Askar et al., 2011; Bielaszewska et al., 2011; Brzuszkiewicz et al., 2011; Cui et al., 2011; Frank et al., 2011; Mellmann et al., 2011; Scheutz et al., 2011), it is difficult to extrapolate on its dormant state behaviour from what has been observed with either EHEC (see above) or EAEC. However, in the case of EAEC, to our knowledge no data on VBNC formation are available until yet. Therefore, we tested here the response of the outbreak strain to various sublethal stresses (nutrient deprivation, copper stress, temperature change) and observed its behaviour in different types of tap water. We showed that the EHEC/EAEC O104:H4 outbreak strain does indeed enter a VBNC state in response to various stresses and resuscitates to become a potentially pathogenic bacterium upon stress relief.

\section{Results}

Culturability of E. coli O104:H4 severely decreased after incubation with copper ions or tap water 1 within a few days

To investigate E. coli O104:H4 2011 outbreak strain persistence in different water microcosms, about $10^{6}$ bacteria per millilitre were inoculated into different nutrient-poor microcosms and the kinetics of culturability was determined. Those conditions were $0.9 \%$ saline (PK), $0.9 \%$ saline containing $500 \mu \mathrm{M}$ CuSO4 $\left(\mathrm{PK}+\mathrm{Cu}^{2+}\right)$, and tap water from two different German regions (town 1 and town 2, i.e. tap 1 and tap 2, see Fig. S1 for water analysis). We included copper ion-mediated stress conditions because several authors have reported that elevated but sublethal concentrations of copper ions can induce a VBNC state in bacteria and/or that resuscitation was possible after stress relief, e.g. in nonpathogenic E. coli (Grey and Steck, 2001), Pseudomonas aeruginosa (Dwidjosiswojo 
et al., 2011), or Agrobacterium tumefaciens and Rhizobium leguminosarum (Alexander et al., 1999). Because low temperatures promote survival and culturability of bacteria (Mizunoe et al., 1999; Grey and Steck, 2001; Ogden et al., 2001; Pinto et al., 2011), all conditions were tested at ambient temperature $\left(23^{\circ} \mathrm{C}\right)$ and at $4^{\circ} \mathrm{C}$. We found that culturability markedly differed between the starvation solutions and the temperature used with the expected general trend to recover more cfu at $4^{\circ} \mathrm{C}$ (Table 1). Bacteria were able to persist and to retain culturability over a period of at least 40 days when incubated in $0.9 \%$ saline, independent of the temperature. Incubations with tap 2 showed culturability over 40 days with a better bacterial recovery at $4^{\circ} \mathrm{C}$ (Table 1). In contrast, when additional stress factors (copper ions or tap 1) were present in the microcosms at $23^{\circ} \mathrm{C}$, culturability rapidly decreased. Zero cfu were determined after 3 days in $0.9 \%$ saline $+\mathrm{Cu}^{2+}$ or tap 1 (Table 1). Among samples incubated at $4^{\circ} \mathrm{C}$, reduction of culturability progressed more slowly; zero cfu were obtained after 5 days in $0.9 \%$ saline $+\mathrm{Cu}^{2+}$ and were almost obtained after 40 days in tap 1 (Table 1). Zero cfu states were verified by plating of $1 \mathrm{ml}$ culture at all shown time points after entry into unculturability as well as at the time points used for resuscitation experiments. In those cases not a single colony grew on the agar even when the plates were incubated for 7 days to allow retarded bacterial growth (data not shown).

Copper ion- or tap 1-stressed non-culturable E. coli O104:H4 populations contain viable bacteria To test whether the unculturable microcosms obtained by starvation and copper-ion or tap 1 stress are unculturable due to bacterial death or loss of colony-forming ability, we performed propidium iodide (Pi)/Syto9 live/dead staining (Boulos et al., 1999; Stocks, 2004) (Fig. 1). The fraction of membranedamaged cells at $4{ }^{\circ} \mathrm{C}$ increased from day 10 to day 40 from $25 \%$ to $44 \%$ respectively, and was about $95 \%$ at day 40 in the copper ion-stressed microcosm at $23^{\circ} \mathrm{C}$ (Fig. $1 \mathrm{~A}$ and $\mathrm{C}$ ). In the completely or almost completely unculturable tap 1 microcosms incubated for 40 days at $4^{\circ} \mathrm{C}$ or $23^{\circ} \mathrm{C}$, about $77 \%$ or $17 \%$ of the bacteria had intact membranes respectively (Fig. 1B and $\mathrm{C}$ ). It was further obvious especially in the incubations with a high proportion of membrane-damaged cells $\left(\mathrm{PK}+\mathrm{Cu}^{2+}\right.$ at $23^{\circ} \mathrm{C}$ and tap 1 at $23^{\circ} \mathrm{C}$ ) that the viable bacteria were associated with microaggregates (Fig. $1 \mathrm{~A}$ and $\mathrm{B}$ ). In summary, our results show that even in microcosms where no cfu was recovered for more than 30 days, a fraction of the E. coli $\mathrm{O} 104: \mathrm{H} 4$ outbreak strain preserved intact cell membranes and therefore was apparently viable.

Resuscitation of copper ion-induced VBNC cells by stress relief and conservation of strain characteristics and fitness after resuscitation

The observation of apparently living bacteria within unculturable populations implied that a proportion of these cells exists in the VBNC state (Xu et al., 1982; Rollins and Colwell, 1986; Kell et al., 1998; Oliver, 2005). Therefore, we assessed whether the unculturable bacteria reassumed a reproductive state, a procedure commonly termed resuscitation. Successful recovery of stress-induced nonpathogenic E. coli and EHEC O157:H7 VBNC bacteria into a culturable state was achieved earlier by stress removal, such as relief of $\mathrm{Cu}^{2+}$ stress by the means of chelators (Grey and Steck, 2001; Liu et al., 2009). VBNC cells produced by various stresses were only able to resuscitate for a limited time and when they entered the VBNC state at $4^{\circ} \mathrm{C}$ (Pinto et al., 2011). Therefore, we focused on resuscitating the $4^{\circ} \mathrm{C}$ copper ion-stressed microcosm after 6 and 11 days of incubation, i.e. at days 1

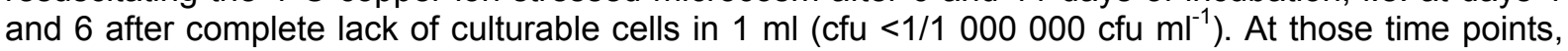
the bacteria were repeatedly washed with cold EDTA and subsequently plated on rich agar medium. A fraction of about $60 \mathrm{cfu} \mathrm{ml}^{-1}$ was recovered by that procedure at day 1 and about $30 \mathrm{cfu} \mathrm{ml}^{-1}$ at day 6 , showing that recovery of the E. coli $0104: \mathrm{H} 4$ outbreak strain into a culturable state was indeed possible (Fig. 2A). No culturable bacteria were recovered by repetitive washing of the bacteria without EDTA (data not shown).

Next, we verified whether six selected colonies exhibited the characteristics of the outbreak strain. First, the colonies all grew on ESBL selective media, due to the presence of the resistance plasmid carrying a CTX-M-15 gene (data not shown) (Askar et al., 2011; Bielaszewska et al., 2011; Brzuszkiewicz et al., 2011; Cui et al., 2011; Frank et al., 2011; Scheutz et al., 2011). Second, all six colonies yielded the characteristic PCR pattern for amplification of stx2, terD, rfbO104 and fliC H4 (Fig. 2B, data shown for three clones) (Bielaszewska et al., 2011). Third, all tested clones shared a comparable DNA macrorestriction pattern (PFGE profile) and plasmid profile with the parental strain, implying no major genetic changes and retention of both large plasmids [83 kbp EAEC virulence plasmid and $90 \mathrm{kbp}$ ESBL antibiotic resistance plasmid (Mellmann et al., 2011)] after resuscitation (Fig. 2C and D, data shown for three clones). Fourth, genetic determinants for the aggregative phenotype, such as the aggR gene coding for the master regulator of the EAEC virulence plasmid and 
chromosomal genes and the aggA (AAF/I) gene coding for the AAF/l fimbrial subunit were present in the resuscitated clones (Fig. 2E, data shown for three clones) (Okeke and Nataro, 2001; Nataro, 2005). Fifth, fitness of three recovered colonies compared with the parental strain, as judged by growth in liquid medium, proved identical (Fig. 2F). These data confirm the recovery of outbreak strainderived colonies and support the claim that the recovered clones are still virulent, as illustrated by the presence of major virulence characteristics like the stx2, aggR and aggA genes.

Cell morphology of different E. coli strains as well as parental, VBNC and resuscitated E. coli O104:H4 We compared cell shapes and dimensions of the non-pathogenic E. coli K12 strain with three different EHEC strains, including the classical EHEC O157:H7, the 2011 German HUS outbreak E. coli, and HUSEC041, the latter two being serotype O104:H4 and EHEC/EAEC strains (Mellmann et al., 2008; 2011; Bielaszewska et al., 2011; Brzuszkiewicz et al., 2011; Scheutz et al., 2011). E. coli K12 exhibited the typical morphology of straight non-aggregating bacilli with length and diameter of about $2 \mu \mathrm{M}$ and $0.6 \mu \mathrm{M}$ respectively (Fig. S2A and D). The E. coli O157:H7 strain (mean length $1.5 \mu \mathrm{M}$ and diameter $0.8 \mu \mathrm{M}$ ) and the two E. coli $\mathrm{O} 104: \mathrm{H} 4$ strains (mean length $1.4 \mu \mathrm{M}$ and diameter $0.9 \mu \mathrm{M}$ ) were significantly shorter and thicker than E. coli K12 (Figs S2 and 3A). Only the two O104:H4 E. coli strains formed aggregative clusters (Figs $\mathrm{S} 2 \mathrm{C}$ and $3 \mathrm{~A}$ ). We observed that broth-grown resuscitated colonies retained the autoaggregative phenotype, implying that the enteroaggregative virulence plasmid is also active in the VBNC revertant (Fig. 3C). We further noted a statistically significant decrease in length and diameter of the VBNC cells (length $\sim 1.2 \mu \mathrm{M}$, diameter $\sim 0.8$ ) compared with both the parental cells and resuscitated cells (length $\sim 1.4 \mu \mathrm{M}$, diameter $\sim 0.9$ ) (Figs 3 and S2).

\section{Discussion}

A number of pathogenic bacteria enter the VBNC state when stressed. We here determined that the $E$. coli O104:H4 isolate linked to the 2011 outbreak of bloody diarrhoea and HUS in Germany persists in a variety of nutrient-poor environments $(0.9 \%$ saline and tap 2$)$ for at least 40 days with only a minor reduction in cfu counts (Table 1 ). The outbreak strain responded to increasing stress with rapidly decreasing cfu counts, as in the case of copper ion-containing microcosms or cultures starving in tap 1 but not tap 2 (Table 1). Reduced temperature $\left(4^{\circ} \mathrm{C}\right)$ supported survival of cells both in the culturable and the non-culturable state compared with the elevated temperature $\left(23^{\circ} \mathrm{C}\right)$ (Table 1 and Fig. 1). This observation is consistent with data from other studies focusing on non-pathogenic $E$. coli and EHEC O157:H7 (Jiang and Chai, 1996;Wang and Doyle, 1998; Grey and Steck, 2001). The copper ion- or tap 1-stressed microcosms at $23^{\circ} \mathrm{C}$ and the copper ion-stressed incubations at $4^{\circ} \mathrm{C}$ reached the state of unculturability (cfu $<1 / 1000000$ ) after $3-5$ days of starvation (Table 1). The $100 \%$ decrease in culturability was not reflected in the number of apparently living cells as demonstrated with Pi/Syto9 staining.

Tap 1 conferred obviously more pressure on the bacteria for entry into a non-culturable state than tap 2. The abiotic parameters determined according to the German Drinking Water Ordinance were almost comparable (Fig. S1). Interestingly, although its copper concentration was less than the concentrations used for the copper ion-stress conditions $\left(\mathrm{PK}+\mathrm{Cu}^{2+}=500 \mu \mathrm{M}\right.$ versus tap $\left.1=1.2 \mu \mathrm{M}\right)$, the copper ion concentration is at least about 15 -fold higher in tap 1 than in tap $2(0.079$ versus

$\left.<0.005 \mathrm{mg} \mathrm{l}^{-1}\right)$. As tap 1 but not tap 2 was disinfected with the addition of chlorine dioxide $\left(0.2 \mathrm{mg} \mathrm{I}^{-1}\right)$ at the water purification plant before delivery to households (personal communication with water purification plants), it is possible that tap 1 contains trace amounts of hypochlorite or hypochlorous acid, despite their low stability.

In this work, we successfully resuscitated a fraction of apparently living but non-culturable cells within the copper ion-stressed microcosms at $4^{\circ} \mathrm{C}$ by relieving stress (Fig. 2A). The number of resuscitated bacteria decreased over time, and we were able to resuscitate cells 1 and 6 days after complete nonculturability was reached (Fig. 2A). Grey and Steck recovered copper-stressed E. coli O157:H7 up to 2 weeks after attaining nonculturability by using a similar EDTA washing approach (Grey and Steck, 2001). We further showed that phenotypic (cell morphology), virulence and other strain-specific characteristics, like stx2, aggR and aggA gene presence, ESBL resistance, and the aggregative phenotype, were preserved after resuscitation (Figs 2 and 3 ).

Our attempts to resuscitate viable cells originating from the $23^{\circ} \mathrm{C}$ copper ion-stressed microcosm as well as the microcosms stressed in tap 1 by using the EDTA washings and subsequent plating on nonsupplemented, catalase-, or sodium pyruvate-supplemented rich agar failed even at early time points 
(data not shown). Our inability to resuscitate bacteria stressed at $23^{\circ} \mathrm{C}$ is consistent with the results of others (Grey and Steck, 2001; Pinto et al., 2011). To improve the extent of resuscitated colonies after copper-ion stress and to establish an adequate recovery protocol for other stress conditions, such as the tap 1 incubations, identification of the exact entry mechanisms into the VBNC state and their stimuli will become necessary.

Interestingly, we noted that in incubations with high proportions of dead cells (copper-ion stress or tap 1 at $23^{\circ} \mathrm{C}$ ), intact bacteria were enriched in microaggregates (Fig. 1). Autoaggregation is a characteristic phenotype of the EAEC pathovar driven by the presence of autoaggregative fimbriae coded on the pAA (plasmid of aggregative adhesion) virulence plasmid (Vial et al., 1988). Both the $E$. coli O104:H4 outbreak strain from 2011 as well as HUSEC041 from 2001 showed autoaggregation in liquid media but not E. coli K12 or classical EHEC 0157:H7 (Figs 3A and S2), implying that the aggregative phenotype of EAEC might not only support its persistence in the human digestive tract (Vial et al., 1988; Pereira et al., 2008) but also may facilitate persistence in the environment. Comparison of the E. coli O104:H4 EHEC/EAEC outbreak strain genome with other E. coli genomes indeed showed that it is most closely related to the EHEC/ EAEC HUSEC041 strain and to the EAEC 55989 strain, isolated from an HIV-infected person suffering from persistent diarrhoea (Mossoro et al., 2002; Touchon et al., 2009; BGI, 2011; Brzuszkiewicz et al., 2011; Mellmann et al., 2011; Rohde et al., 2011)

Our study shows that the existence of VBNC state E. coli O104:H4 may be an additional factor to consider in successfully detecting this pathogen in an environmental or food source. In many cases, poor sensitivity of gene detection is due to low loads of the target bacterium in

food or environmental samples and/or the presence of PCR inhibitors that may co-purify with the target DNA (Gonzalez et al., 1999). Thus, enrichment of the target pathogen before PCR verification is necessary, which in the case of VBNC cells could lead to amplification of other bacterial DNA but likely not to resuscitation of the VBNC cell fraction. We therefore recommend taking into account the existence of VBNC bacteria for both culture-based as well as gene detection-based (PCR) protocols. In the future, it will therefore be important to identify the specific factors involved in triggering resuscitation of VBNC bacteria.

\section{Experimental procedures}

Bacterial strains and growth conditions

Escherichia coli strains K12 (C600), 0157:H7 (EDL933), 0104:H4 (RKI 01-09591), which is listed in the HUSEC collection as HUSEC041 (Mellmann et al., 2008), and O104:H4 (RKI 11-02027), were routinely grown at $37^{\circ} \mathrm{C}$ for 1 day on nutrient agar (NA) plates (Oxoid) unless otherwise stated, or when appropriate cultured in Luria-Bertani (LB) broth at $37^{\circ} \mathrm{C}$ with shaking (250 r.p.m.). The latter $E$. coli O104:H4 strain was isolated and characterized at the National Reference Centre for Salmonella and other Enteric Bacterial Pathogens (Robert Koch-Institut, Germany) within the 2011 German outbreak from a HUS patient and shows the typical outbreak strain markers: serotype 0104:H4, stx2 positive, eae negative, aggR positive, aggA(AAF/l) positive, ESBL resistance (Frank et al., 2011).

Growth curves were generated using the Bioscreen C device (Labsystems, Helsinki, Finland). $200 \mu \mathrm{l}$ of culture containing 200 bacteria were inoculated into the wells of a 100- well plate. Growth was monitored at $37^{\circ} \mathrm{C}$ with moderate shaking ( 40 move instruction setting) by measuring optical densities at $600 \mathrm{~nm}$ wavelength in 20 min intervals until stationary phase was reached.

\section{Generation of starvation microcosms}

To generate microcosms, E. coli O104:H4 (11-02027) was grown overnight on chromID ESBL agar medium (bioMerieux, Germany) to ensure ESBL plasmid retention. Bacteria were then adjusted to $2 \mathrm{x}$ $10^{8} \mathrm{cfu} \mathrm{\textrm {ml } ^ { - 1 }}$ by inoculating bacteria into sterile $0.9 \%$ saline to an OD660 of $0.3 .40 \mathrm{ml}$ filter-sterilized starvation solutions (tap water originating from town 1 (tap 1), tap water from town 2 (tap 2), $0.9 \%$ saline (PK), and saline containing $500 \mu \mathrm{M}$ CuSO4) were inoculated with $200 \mu \mathrm{l}$ of bacterial suspensions yielding a final bacterial density of $10^{6} \mathrm{cfu} \mathrm{ml}^{-1}$ each. Tap 1 and 2 were chosen for the experiments with the E. coli O104:H4 2011 outbreak strain due to the radical differences in culturability kinetics of different Salmonella enterica strains, which has been previously observed ( $P$. Aurass and A. Flieger, unpubl. obs.). The abiotic parameters of the two tap waters were determined according to the German Drinking Water Ordinance (Fig. S1). Since tap 1 but not tap 2 was disinfected with the 
addition of chlorine dioxide $\left(0.2 \mathrm{mg} \mathrm{l}^{-1}\right)$ at the water purification plant before delivery to the households, it is possible that tap 1 contains trace amounts of hypochlorite and hypochlorous acid (personal communication with the water purification plants). Bacterial cfu in the inoculum were determined by plating of serially diluted samples. Each experimental condition was set up in duplicates in $50 \mathrm{ml}$ plastic tubes. Duplicate samples of each starvation condition were incubated at $23^{\circ} \mathrm{C}$ or $4^{\circ} \mathrm{C}$ respectively.

To determine the state of culturability of suspensions, $10 \mu \mathrm{l}$ aliquots were spot plated onto NA plates and grown for 1 day until culturable counts dropped below detection. Subsequently, $1 \mathrm{ml}$ aliquots were plated until cfu dropped below $1 / 10^{6}$, and cultures with less than one cfu in $10^{6}$ total bacteria are referred to as zero cfu state cultures.

Determination of live/dead state and microscopy

For live/dead discrimination $1 \mathrm{ml}$ culture aliquots were removed and stained with the propidium iodide (Pi)/Syto9 dyes, both included in the Live/Dead BacLight Kit (Invitrogen L7007). For this purpose, 0.5 $\mu \mathrm{l}$ solution $\mathrm{A}$ (containing $1.67 \mu \mathrm{M} \mathrm{Pi}+1.67 \mu \mathrm{M}$ Syto9) and $1 \mu$ l of solution $\mathrm{B}$ (containing $18.3 \mu \mathrm{M} \mathrm{Pi}+$ $1.67 \mu \mathrm{M}$ Syto9) were added directly to the culture aliquot and were incubated for $15 \mathrm{~min}$ in the dark. Subsequently, stained suspensions were filtered through black nucleopore filters (Pall) and imaged at 400- or 1000- fold magnification in a Nikon Eclipse fluorescence microscope. Individually stained cells were either automatically counted using the CellC software (Selinummi et al., 2005) or counted manually for control purposes.

\section{Brightfield microscopy}

DIC images were generated using a Nikon Eclipse microscope equipped with nomarsky optics. Bacteria were imaged on agarose coated glass slides with 1000-fold magnification.

\section{Resuscitation of copper ion-stressed bacteria}

One millilitre aliquots of microcosms containing copper ionstressed VBNC bacteria generated at $4^{\circ} \mathrm{C}$ were treated with $1 / 1000$ volume of $500 \mu \mathrm{M}$ EDTA and incubated $3 \mathrm{~min}$ on ice. Subsequently, bacteria were pelleted by centrifugation in a refrigerated centrifuge $(5 \mathrm{~min} 7000 \mathrm{~g})$. Supernatants were removed, and bacteria were resuspended in $1 \mathrm{ml}$ cold $500 \mu \mathrm{M}$ EDTA in $0.9 \%$ saline solution. The wash step was repeated once more, and bacteria were finally resuspended to the original volume in $0.9 \%$ saline. $100 \mu \mathrm{l}$ aliquots (theroretically containing $10^{5}$ bacteria) were spot plated on NA or NA containing $2000 \mathrm{U}$ catalase (Sigma-Aldrich). In parallel, controls containing non-EDTA washed aliquots of the same respective unculturable microcosm were plated in $100 \mu \mathrm{l}$ spots and $1 \mathrm{ml}$ patches onto NA and NA containing $2000 \mathrm{U}$ catalase to confirm the inability of the included bacteria to form colonies. Control plates and plates containing EDTAwashed bacteria were incubated at $25^{\circ} \mathrm{C}$ for 7 days and checked daily for cfu. After 3 days, no further increase in cfu formation was observed in all subsequent experiments.

Multiplex PCR of resuscitated bacteria for confirmation of E. coli O104:H4 characteristics

Multiplex PCR was carried out using the primer pairs LP43/LP44, TerD1/TerD2, 104rbfO-f/104rbf-r and fliCH4-a/fliCH4-b as described elsewhere (Bielaszewska et al., 2011). PCR was carried out using a thermocycler 'Flexcycler' (analyticjena, Jena, Germany) and Taq DNA polymerase (New England Biolabs, Frankfurt am Main, Germany).

$P C R$ for confirmation of $P A A$ virulence gene loci

The aggA (AAF/I) PCR was performed according to (Tsai et al., 2003). The PCR for the aggR gene was carried out according to Czeczulin and colleagues (1999).

\section{Characterization of plasmids and PFGE analysis}

Large plasmids were isolated and plasmid profiles were analysed by agarose gel electrophoresis according to Prager and colleagues 2005 (Prager et al., 2005). PFGE was performed following the PulseNet protocol of the CDC, Atlanta (Hunter et al., 2005). The PFGE Patterns were analysed with BioNumerics, Version 5.1 (Applied Maths, BVBA, Belgium). 


\section{Acknowledgements}

We thank Martin Mielke and Omar Metwally for critical reading of the manuscript. We acknowledge Gerlinde Bartel, Ute Strutz and Ute Siewert for excellent technical assistance.

\section{References}

Adachi, J.A., Jiang, Z.D., Mathewson, J.J., Verenkar, M.P., Thompson, S., and Martinez-Sandoval, F et al. (2001) Enteroaggregative Escherichia coli as a major etiologic agent in traveler's diarrhea in 3 regions of the world. Clin Infect Dis 32: 1706-1709.

Alexander, E., Pham, D., and Steck, T.R. (1999) The viablebut-nonculturable condition is induced by copper in Agrobacterium tumefaciens and Rhizobium leguminosarum. Appl Environ Microbiol 65: 3754-3756.

Askar, M., Faber, M., Frank, C., Bernard, H., Gilsdorf, A., Fruth, A., et al. (2011) Update on the ongoing outbreak of haemolytic uraemic syndrome due to Shiga toxinproducing Escherichia coli (STEC) serotype O104, Germany, May 2011. Euro Surveill 16: pii19883.

Barer, M.R., and Harwood, C.R. (1999) Bacterial viability and culturability. Adv Microb Physiol 41: 93137.

BfR (2011) Bundesinstitut für Risikobewertung. [WWW document].URL http://www.bfr.bund.de/en/press_information/2011/17/ehec_outbreak_bfr_confirms_contamination_of sprouts_with_0104_h4-70976.html. Press release from June 11th. Ref Type: Pamphlet. $\overline{B f R+B V L+R K I}$ (2011) Bundesinstitut für Risikobewertung, Bundesamt für Verbraucherschutz und Lebensmittelsicherheit and Robert Koch-Institute. [WWW document]. URL http://www.bfr.bund.de/en/press_information/2011/21/ehec_0104_h4_outbreak_event_in_germany_cl arified_sprouts_of_fenugreek_seeds_imported_from_egypt_as_underlying_cause-83273.html. Press release of July 5th. Ref, Type: Pamphlet.

BGI (2011) Beijing genome institute, sequencing data of Escherichia coli ty-2482 isolate. [WWW document]. URL http://www.genomics.cn/en/news_show.php?type=show\&id=644 [Accessed: 28 June 2011]. Ref Type: Data File.

Bielaszewska, M., Mellmann, A., Zhang, W., Kock, R., Fruth, A., Bauwens, A., et al. (2011) Characterisation of the Escherichia coli strain associated with an outbreak of haemolytic uraemic syndrome in Germany, 2011: a microbiological study. Lancet Infect Dis 11: 671-676.

Bolton, D.J., Byrne, C.M., Sheridan, J.J., McDowell, D.A., and Blair, I.S. (1999) The survival characteristics of a nontoxigenic strain of Escherichia coli O157:H7. J Appl Microbiol 86: 407-411.

Boulos, L., Prevost, M., Barbeau, B., Coallier, J., and Desjardins, R. (1999) LIVE/DEAD BacLight(TM): application of a new rapid staining method for direct enumeration of viable and total bacteria in drinking water. J Microbiol Methods 37: 77-86.

Brzuszkiewicz, E., Thurmer, A., Schuldes, J., Leimbach, A., Liesegang, H., Meyer, F.D., et al. (2011) Genome sequence analyses of two isolates from the recent Escherichia coli outbreak in Germany reveal the emergence of a new pathotype: Entero-Aggregative-Haemorrhagic Escherichia coli (EAHEC). Arch Microbiol. Epub ahead of print.

Colwell, R.R., Brayton, P.R., Grimes, D.J., Roszak, D.B., Huq, S.A., and Palmer, L.M. (1985) Viable but non-culturable Vibrio cholerae and related pathogens in the environment: implications for release of genetically engineered microorganisms. Nat Biotechnol 3: 817-820.

Colwell, R.R., Brayton, P., Herrington, D., Tall, B., Huq, A., and Levine, M.M. (1996) Viable but nonculturable Vibrio cholerae 01 revert to a culturable state in the human intestine. World $\mathrm{J}$ Microbiol Biotechnol 12: 28-31.

Cui, Y., Qin, J., Zhao, X., Rohde, H., Liang, T., Wolters, M., et al. (2011) Identification of the hybrid strain responsible for Germany food-poisoning outbreak by polymerase chain reaction. J Clin Microbiol. Epub ahead of print.

Czeczulin, J.R., Whittam, T.S., Henderson, I.R., Navarro-Garcia, F., and Nataro, J.P. (1999) Phylogenetic analysis of enteroaggregative and diffusely adherent Escherichia coli. Infect Immun 67: 2692-2699.

Dwidjosiswojo, Z., Richard, J., Moritz, M.M., Dopp, E., Flemming, H.C., and Wingender, J. (2011) Influence of copper ions on the viability and cytotoxicity of Pseudomonas aeruginosa under conditions relevant to drinking water environments. Int J Hyg Environ Health. Epub ahead of print.

Frank, C., Werber, D., Cramer, J.P., Askar, M., Faber, M., Heiden, M.A., et al. (2011) Epidemic Profile of Shiga-Toxin-Producing Escherichia coli O104:H4 Outbreak in Germany - Preliminary Report. N Engl J Med. Epub ahead of print. 
Gault, G., Weill, F., Mariani-Kurkdjian, P., Jourdan-da, S.N., King, L., Aldabe, B., et al. (2011) Outbreak of haemolytic uraemic syndrome and bloody diarrhoea due to Escherichia coli O104:H4, south-west France, June 2011. Euro Surveill 16: 19905.

Gonzalez, I., Garcia, T., Fernandez, A., Sanz, B., Hernandez, P.E., and Martin, R. (1999) Rapid enumeration of Escherichia coli in oysters by a quantitative PCR-ELISA. J Appl Microbiol 86: 231-236. Grey, B., and Steck, T.R. (2001) Concentrations of copper thought to be toxic to Escherichia coli can induce the viable but nonculturable condition. Appl Environ Microbiol 67: 5325-5327.

Harrington, S.M., Strauman, M.C., Abe, C.M., and Nataro, J.P. (2005) Aggregative adherence fimbriae contribute to the inflammatory response of epithelial cells infected with enteroaggregative Escherichia coli. Cell Microbiol 7: 1565- 1578.

Huang, D.B., Mohanty, A., DuPont, H.L., Okhuysen, P.C., and Chiang, T. (2006) A review of an emerging enteric pathogen: enteroaggregative Escherichia coli. J Med Microbiol 55: 1303-1311.

Hunter, S.B., Vauterin, P., Lambert-Fair, M.A., Van Duyne, M.S., Kubota, K., Graves, L., et al. (2005) Establishment of a universal size standard strain for use with the PulseNet standardized pulsed-field gel electrophoresis protocols: converting the national databases to the new size standard. $\mathrm{J}$ Clin Microbiol 43: 1045-1050.

Hussong, D., Colwell, R.R., O’Brien, M., Weiss, E., Pearson, A.D., Weiner, R.M., and Burge, W.D. (1987) Viable Legionella pneumophila not detectable by culture on agar media. Nat Biotechnol 5: 947-950.

Jiang, X., and Chai, T.J. (1996) Survival of Vibrio parahaemolyticus at low temperatures under starvation conditions and subsequent resuscitation of viable, nonculturable cells. Appl Environ Microbiol 62: 1300-1305.

Jiang, X., Morgan, J., and Doyle, M.P. (2002) Fate of Escherichia coli O157:H7 in manure-amended soil. Appl Environ Microbiol 68: 2605-2609.

Jones, D.M., Sutcliffe, E.M., and Curry, A. (1991) Recovery of viable but non-culturable Campylobacter jejuni. J Gen Microbiol 137: 2477-2482.

Kaper, J.B., Nataro, J.P., and Mobley, H.L. (2004) Pathogenic Escherichia coli. Nat Rev Microbiol 2: 123-140.

Karch, H., and Bielaszewska, M. (2001) Sorbitol-fermenting Shiga toxin-producing Escherichia coli 0157:H(-) strains: epidemiology, phenotypic and molecular characteristics, and microbiological diagnosis. J Clin Microbiol 39: 2043- 2049.

Kell, D.B., Kaprelyants, A.S., Weichart, D.H., Harwood, C.R., and Barer, M.R. (1998) Viability and activity in readily culturable bacteria: a review and discussion of the practical issues. Antonie Van Leeuwenhoek 73: 169-187.

Liu, Y., Wang, C., Tyrrell, G., Hrudey, S.E., and Li, X.F. (2009) Induction of Escherichia coli O157:H7 into the viable but non-culturable state by chloraminated water and river water, and subsequent resuscitation. Environ Microbiol 1: 155-161.

Liu, Y., Wang, C., Tyrrell, G., and Li, X.F. (2010) Production of Shiga-like toxins in viable but nonculturable Escherichia coli O157:H7. Water Res 44: 711-718.

McKay, A.M. (1992) Viable but non-culturable forms of potentially pathogenic bacteria in water. Lett Appl Microbiol 14: 129-135.

Mellmann, A., Bielaszewska, M., Kock, R., Friedrich, A.W., Fruth, A., Middendorf, B., et al. (2008) Analysis of collection of hemolytic uremic syndrome-associated enterohemorrhagic Escherichia coli. Emerg Infect Dis 14: 1287-1290.

Mellmann, A., Harmsen, D., Cummings, C.A., Zentz, E.B., Leopold, S.R., Rico, A., et al. (2011) Prospective genomic characterization of the German enterohemorrhagic Escherichia coli $0104: \mathrm{H} 4$ outbreak by rapid next generation sequencing technology. PLOS ONE 6: e22751.

Mizunoe, Y., Wai, S.N., Takade, A., and Yoshida, S. (1999) Restoration of culturability of starvationstressed and lowtemperature-stressed Escherichia coli $\mathrm{O} 157$ cells by using $\mathrm{H} 2 \mathrm{O} 2$-degrading compounds. Arch Microbiol 172: 63-67.

Mossoro, C., Glaziou, P., Yassibanda, S., Lan, N.T.P., Bekondi, C., Minssart, P., et al. (2002) Chronic diarrhea, hemorrhagic colitis, and hemolytic-uremic syndrome associated with HEp-2 adherent Escherichia coli in adults infected with human immunodeficiency virus in Bangui, Central African Republic. J Clin Microbiol 40: 3086-3088.

Nataro, J.P. (2005) Enteroaggregative Escherichia coli pathogenesis. Curr Opin Gastroenterol 21: 48.

Ogden, L.D., Fenlon, D.R., Vinten, A.J., and Lewis, D. (2001) The fate of Escherichia coli O157 in soil and its potential to contaminate drinking water. Int J Food Microbiol 66: 111-117.

Okeke, I.N., and Nataro, J.P. (2001) Enteroaggregative Escherichia coli. Lancet Infect Dis 1: 304-313. Oliver, J.D. (2005) The viable but nonculturable state in bacteria. J Microbiol 43: 93-100.

Oliver, J.D. (2010) Recent findings on the viable but nonculturable state in pathogenic bacteria. FEMS Microbiol Rev 34: 415-425. 
Oliver, J.D., and Bockian, R. (1995) In vivo resuscitation, and virulence towards mice, of viable but nonculturable cells of Vibrio vulnificus. Appl Environ Microbiol 61: 2620-2623.

Pennington, H. (2011) Escherichia coli O104, Germany 2011. Lancet Infect Dis 11: 652-653.

Pereira, A.C., Britto-Filho, J.D., Josq de Carvalho, J., de Luna, M.G., and Rosa, A.C. (2008) Enteroaggregative Escherichia coli (EAEC) strains enter and survive within cultured intestinal epithelial cells. Microb Pathog 45: 310- 314.

Pinto, D., Almeida, V., Almeida, S.M., and Chambel, L. (2011) Resuscitation of Escherichia coli VBNC cells depends on a variety of environmental or chemical stimuli. J Appl Microbiol 110: 1601-1611.

Prager, R., Annemuller, S., and Tschape, H. (2005) Diversity of virulence patterns among shiga toxinproducing Escherichia coli from human clinical cases-need for more detailed diagnostics. Int J Med Microbiol 295: 29-38.

Rahman, I., Shahamat, M., Kirchman, P.A., Russek-Cohen, E., and Colwell, R.R. (1994) Methionine uptake and cytopathogenicity of viable but nonculturable Shigella dysenteriae type 1. Appl Environ Microbiol 60: 3573-3578.

Rahman, I., Shahamat, M., Chowdhury, M.A., and Colwell, R.R. (1996) Potential virulence of viable but nonculturable Shigella dysenteriae type 1. Appl Environ Microbiol 62: 115-120.

RKI (2011a) Robert Koch-Institute, information on EHEC/ HUS outbreak, continuously actualized. [WWW document]. URL http://www.rki.de/cln_162/nn_205760/DE/Home/InfoHUS, templateld=raw, property=publicationFile.pdf/Info-HUS.pdf. Ref Type: Pamphlet.

RKI (2011b) Robert Koch-Institute, technical report of EHEC/HUS outbreak from June 30th, 2011. [WWW document].

URL http://www.rki.de/cIn_162/nn_217400/EN/Home/EHEC_Report,templateld=raw, property=publicationF ile.pdf/EHEC_Report.pdf. Ref Type: Pamphlet.

Rohde, H., Qin, J., Cui, Y., Li, D., Loman, N.J., Hentschke, M., et al. (2011) Open-source genomic analysis of Shiga-toxinproducing E. coli O104:H4. N Engl J Med 365: 718-724.

Rollins, D.M., and Colwell, R.R. (1986) Viable but nonculturable stage of Campylobacter jejuni and its role in survival in the natural aquatic environment. Appl Environ Microbiol 52: 531-538.

Saha, S.K., Saha, S., and Sanyal, S.C. (1991) Recovery of injured Campylobacter jejuni cells after animal passage. Appl Environ Microbiol 57: 3388-3389.

Scheutz, F., Moller, N.E., Frimodt-Moller, J., Boisen, N., Morabito, S., Tozzoli, R., et al. (2011) Characteristics of the enteroaggregative Shiga toxin/verotoxin-producing Escherichia coli O104:H4 strain causing the outbreak of haemolytic uraemic syndrome in Germany, May to June 2011. Euro Surveill 16: 19889.

Selinummi, J., Seppala, J., Yli-Harja, O., and Puhakka, J.A. (2005) Software for quantification of labeled bacteria from digital microscope images by automated image analysis. Biotechniques 39: 859-863.

Smith, J.J., Howington, J.P., and McFeters, G.A. (1994) Survival, physiological response and recovery of enteric bacteria exposed to a polar marine environment. Appl Environ Microbiol 60: 2977-2984.

Steinert, M., Emody, L., Amann, R., and Hacker, J. (1997) Resuscitation of viable but nonculturable Legionella pneumophila Philadelphia JR32 by Acanthamoeba castellanii. Appl Environ Microbiol 63: 2047-2053.

Stern, N.J., Jones, D.M., Wesley, I.V., and Rollins, D.M. (1994) Colonization of chicks by nonculturable Campylobacter spp. Lett Appl Microbiol 18: 333-336.

Stocks, S.M. (2004) Mechanism and use of the commercially available viability stain, BacLight. Cytometry 61A: 189- 195.

Tarr, P.I., Gordon, C.A., and Chandler, W.L. (2005) Shigatoxin-producing Escherichia coli and haemolytic uraemic syndrome. Lancet 365: 1073-1086.

Touchon, M., Hoede, C., Tenaillon, O., Barbe, V., Baeriswyl, S., Bidet, P., et al. (2009) Organised genome dynamics in the Escherichia coli species results in highly diverse adaptive paths. PLoS Genet 5: e1000344.

Tsai, C.C., Chen, S.Y., and Tsen, H.Y. (2003) Screening the enteroaggregative Escherichia coli activity and detection of the aggA, aafA, and astA genes with novel PCR primers for the Escherichia coli isolates from diarrhea cases in Taiwan. Diagn Microbiol Infect Dis 46: 159-165.

Vial, P.A., Robins-Browne, R., Lior, H., Prado, V., Kaper, J.B., Nataro, J.P., et al. (1988) Characterization of enteroadherent-aggregative Escherichia coli, a putative agent of diarrheal disease. $\mathrm{J}$ Infect Dis 158: 70-79.

Wang, G., and Doyle, M.P. (1998) Survival of enterohemorrhagic Escherichia coli O157:H7 in water. J Food Prot 61: 662-667.

Wingender, J., and Flemming, H.C. (2011) Biofilms in drinking water and their role as reservoir for pathogens. Int J Hyg Environ Health. Epub ahead of print. 
Xu, H., Roberts, N., Singleton, F.L., Attwell, R.W., Grimes, D.J., and Colwell, R.R. (1982) Survival and viability of nonculturable Escherichia coli and Vibrio cholerae in the estuarine and marine environment. Microb Ecol 8: 313- 323.

Yaron, S., and Matthews, K.R. (2002) A reverse transcriptase-polymerase chain reaction assay for detection of viable Escherichia coli O157:H7: investigation of specific target genes. J Appl Microbiol 92: 633-640.

\section{Tables and Figures}

Table 1. Persistence and non-culturability of E. coli O104:H4 2011 outbreak strain (11-02027) in different environments.

\begin{tabular}{|c|c|c|c|c|}
\hline & cfu $\mathrm{ml}^{-1}$ at day 0 & 0 cfu state at day & cfu $\mathrm{ml}^{-1}$ at day 10 & cfu $\mathrm{ml}^{-1}$ at day 40 \\
\hline \multicolumn{5}{|l|}{$4^{\circ} \mathrm{C}$} \\
\hline PK & $9 \times 10^{5}$ & - & n.d. & $5 \times 10^{5}$ \\
\hline $\mathrm{PK}+\mathrm{Cu}^{2+}$ & & 5 & 0 & 0 \\
\hline Tap 1 & & - & $7 \times 10^{3}$ & $2 \times 10^{1}$ \\
\hline Tap 2 & & - & n.d. & $3 \times 10^{5}$ \\
\hline \multicolumn{5}{|l|}{$23^{\circ} \mathrm{C}$} \\
\hline PK & $9 \times 10^{5}$ & - & n.d. & $3 \times 10^{5}$ \\
\hline $\mathrm{PK}+\mathrm{Cu}^{2+}$ & & 3 & 0 & 0 \\
\hline Tap 1 & & 3 & 0 & 0 \\
\hline Tap 2 & & - & n.d. & $2 \times 10^{4}$ \\
\hline
\end{tabular}

n.d., not determined; results are representative for two additional independent experiments.

Figure 1. Copper ion- or tap 1-stressed, non-culturable E. coli O104:H4 populations contain viable bacteria. A. 10 days incubated E. coli O104:H4 (11-02027) populations in $0.9 \%$ saline (culturable control) or $0.9 \%$ saline $+500 \mu \mathrm{M} \mathrm{Cu}^{2+}$ (did not contain culturable bacteria) both at $4{ }^{\circ} \mathrm{C}$, and 40 days incubated $\mathrm{Cu}^{2+-}$ stressed, unculturable populations at $4^{\circ} \mathrm{C}$ and $23^{\circ} \mathrm{C}$ were double stained with propidium iodide $(\mathrm{Pi})$ and Syto9 to determine bacterial viability. Images were taken at 1000 -fold magnification by means of fluorescence microscopy. Boxes show magnified bacterial aggregates with membrane-intact living (green $=\mathrm{Pi}$-/Syto9+) and membrane-damaged apparently dead $(\mathrm{red}=$ $\mathrm{Pi}+/$ Syto9-) cells found in all microcosms. B. Incubations for 40 days at $4^{\circ} \mathrm{C}$ (low fraction $<0.01 \%$ still culturable) or $23^{\circ} \mathrm{C}$ (non-culturable) in tap 1 still contain living bacteria. C. Mean percentages of living and dead bacteria within the incubated cultures were determined. Increased temperature significantly reduced the proportion of viable cells from $56 \%$ at $4{ }^{\circ} \mathrm{C}$ to $5 \%$ at $23^{\circ} \mathrm{C}\left(\mathrm{Cu}^{2+}\right.$ stress $)$ or from $77 \%$ at $4{ }^{\circ} \mathrm{C}$ to $17 \%$ at $23^{\circ} \mathrm{C}$ (tap 1 stress) respectively. The results represent the means of at least 500 counted bacteria per sample $(P<0.01$ for fractions of dead cells; Student's $t$-test). Experiments were performed in duplicate cultures and are representative for two additionally performed independent experiments.
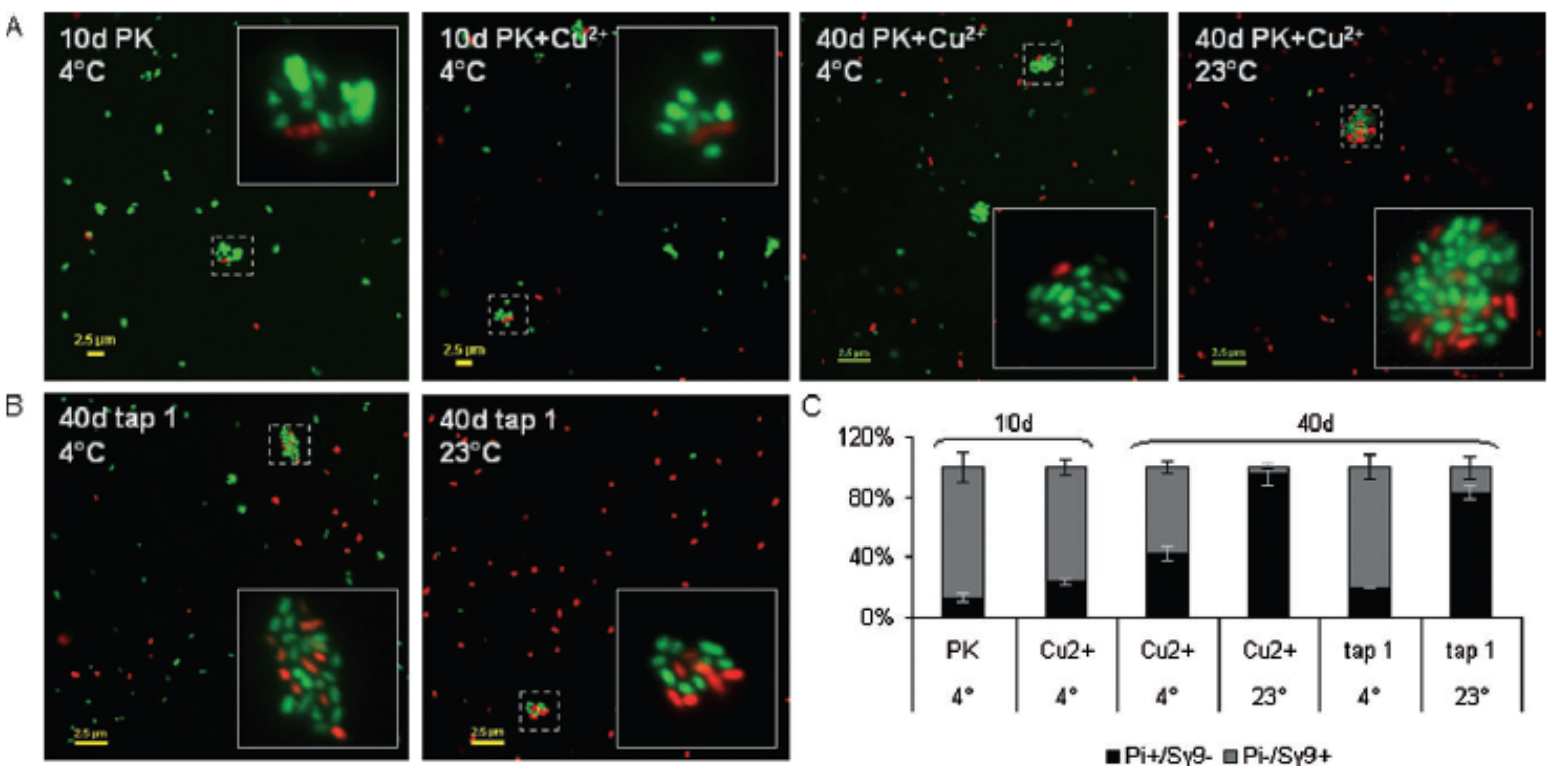

-Pi+/Sy9- aPi-/Sy9+ 
Figure 2. Resuscitation of copper ion-induced VBNC cells and conservation of strain characteristics. Within the 6 and 11 days (corresponding to 1 and 6 days after 0 cfu state respectively) $\mathrm{Cu}^{2+}$ treated non-culturable $E$. coli $0104: \mathrm{H} 4$ (11-02027) population at $4^{\circ} \mathrm{C}$, colony-forming ability was restored for a fraction of bacteria by repetitively washing the bacteria with cold $500 \mu \mathrm{M}$ EDTA in $0.9 \%$ saline and subsequent plating onto rich medium (NA) supplemented with $2000 \mathrm{U}$ catalase per plate (A). To confirm the identity with the parental strain and preservation of strain characteristics after resuscitation, resuscitated clones were analysed for: strain characteristic and virulence loci $(1=s t \times 2,2$ $=\operatorname{ter} \mathrm{D}, 3=$ rbfO104, $4=$ fliC H4) by PCR (B), genetic similarity via Xbal macrorestriction and PFGE (C), plasmid profile (showing the $90 \mathrm{kbp}$ antibiotic resistency plasmid and the $83 \mathrm{kbp}$ pAA EAEC virulence plasmid (Mellmann et al., 2011) (D), retention of the pAA virulence plasmid by PCR amplification of aggR and aggA $(E)$, and comparable growth kinetics starting growth from a low inoculum $\left(1000 \mathrm{cfu} \mathrm{ml}^{-1}\right)$ in LB broth $(\mathrm{F})$. Abbreviations: parental strain $(+)$, three representative resuscitated clones ( $r s 1,2,3)$, PCR negative control containing water (-).

A

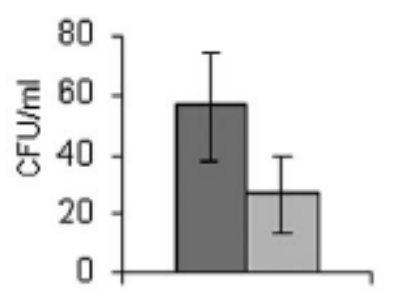

arecovery after 1 day

arecovery after 6 days

D

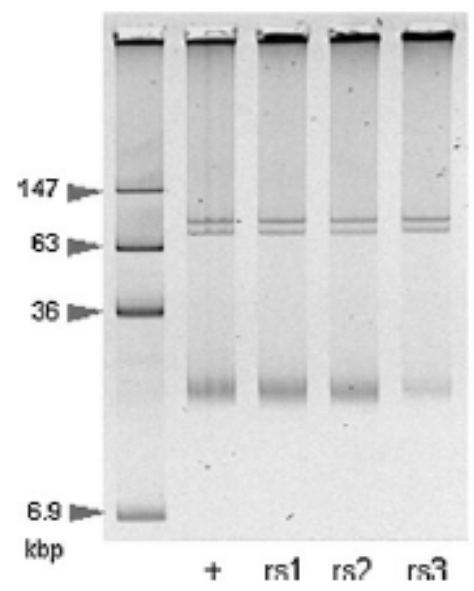

$B$

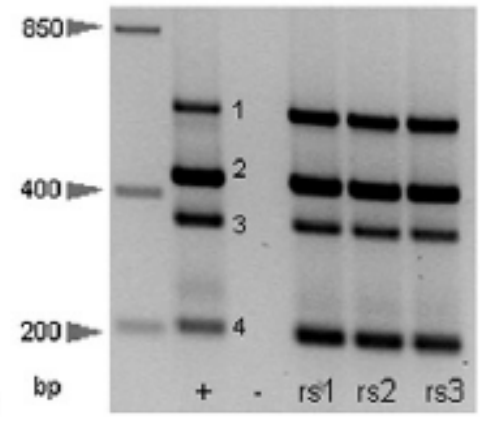

E
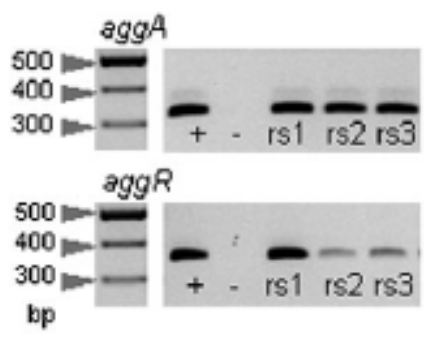
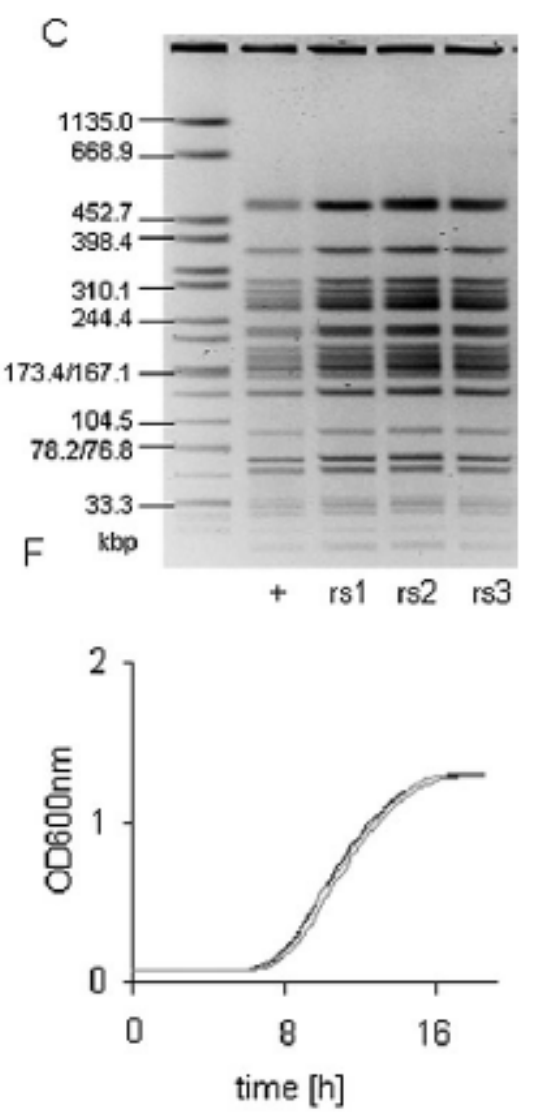
Figure 3. The broth-grown parental E. coli O104:H4 2011 outbreak strain and the resuscitated strain show characteristic autoaggregation. DIC images of parental (A), of 10 day copper ion-stressed VBNC (B), and resuscitated (C) E. coli O104:H4 2011 outbreak strain clones are shown. Strains were grown overnight in LB broth to stationary phase and were then imaged at 1000-fold magnification. DIC image (1000-fold magnification) of the 10 days at $4^{\circ} \mathrm{C}$ copper ion-stressed population containing VBNC cells (VBNC) shows dwarfing of bacteria compared with the resuscitated (culturable) population after enrichment in nutrient-rich broth $(B, C$ and $D$ ). The results represent the means and standard deviations of at least 200 measured cells per sample $(P<0.01$ for diameter and length; Student's $t$ test).
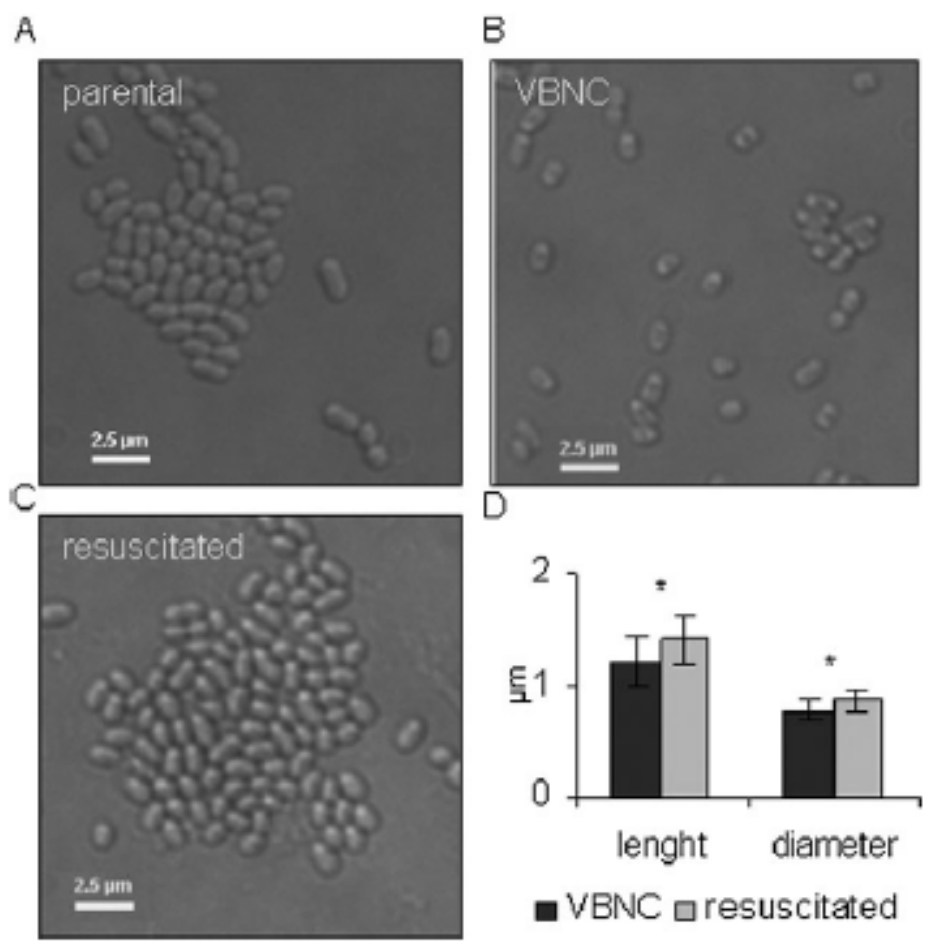